\title{
CHRISTIAN EGALITARIANISM: THE BOOK OF THE CITY OF LADIES VERSUS THE BIBLE
}

\author{
Merve AYDOĞDU ${ }^{1}$
}

\begin{abstract}
The Bible is the sacred text of Christianity and Judaism and it contains stories about the lives of the people in the past. Some of these stories are about the women. In them, the women are either represented in derogatory terms such as sinful- being the descendants of Eve or portrayed less important than the men. In both cases, the women are not given the position they deserve and the male-female inequality inherent in the society gains strength with the holy book. On the other hand, taking some verses of it as their mainstay, Christian egalitarians defend that both sexes are equal in the eyes of God. Similarly, 14th century French author Christine de Pizan purports that the women are as intelligent and powerful as the men. To this end, she provides us with many woman portraits. Her stories function as a reply to the ones in the Bible and try to refute the misrepresentation of the women in it. Hence, it would not be wrong to state that she was among the first defenders of equality between the sexes and that she was courageous enough to stand up to the holy book.
\end{abstract}

Key Words: Christianity, Christian Egalitarianism, Christine de Pizan, Feminism, the Scripture.

\footnotetext{
${ }^{1}$ Research Assistant.Middle East Technical University, Department of Foreign Language Education. maydogdu@metu.edu.tr
} 


\title{
HR ST YAN EŞ TL Ğ : K TAB-I MUKADDES'E KARŞI ŞEHR N KADINLARI
}

\begin{abstract}
ÖZET
Hristiyanlık inancının kutsal kitabı ncil, insan yaşamından kesitler sunan ve tarihi gerçeklere dayanan hikâyeler barındıran bir metindir. Bu hikâyelerin bir kısmında kadınlara değinildiğini görmek mümkündür. Ne var ki, ncil' deki bazı kadın temsillerinde kadınlara bazen ikincil, alçaltıcı özellikler yüklenirken, bazılarında Havva modeline uygun olarak kadınlar birer yıkıcı unsur, birer günahkâr olarak görülmüşlerdir. Her durumda, kadına erkeğin yanında hak ettiği değer verilmemiştir. Toplumsal düzende var olan kadın-erkek eşitsizliği, ncil'in de etkisiyle daha da güçlenmiştir. Hristiyan inancındaki eşitlik savunucuları ise, ncil'deki bazı ayetleri temel alarak Tanrı katında kadın ve erkeğin eşit yaratıldığını ve eşit olduğunu savunarak, iki cinsiyet arasındaki ayrıma karşı çıkar. lk feministlerden sayılan 14. yüzyıl Fransız yazar Christine de Pizan da eserinde kadınların erkeklerden daha aşağı konumda olmadıklarını göstermek amacıyla çeşitli güçlü ve akıllı kadınları gözler önüne serer. Anlattığı hikâyeler ncil'e cevap niteliği taşımakla birlikte, kadınların kutsal kitapta resmedildikleri gibi olmadığını/ olmaması gerektiğini savunur. Bu temelde, Pizan'ın hem eşitlikçi düşüncenin ilk savunucularından olduğunu hem de ncil'e karşı çıkabilme cesaretini gösterdiğini söylemek yanlış olmayacaktır.
\end{abstract}

Anahtar Kelimeler: Hristiyanlık, Hristiyanlıkta Eşitlik, Christine de Pizan, Feminizm, Kutsal Kitap.

The Middle Ages, beginning with the fall of the Western Roman Empire and lasting till the $15^{\text {th }}$ century, witnessed the dominance of Christianity taught by Jesus Christ and his Apostles in the Bible. During the era, Catholicism was the only recognized sect and the religion influenced the people from all layers of the society. That is to say, from the serfs to the peasants, from the landlords to the nobles, all members of the feudal system were under the hegemony of the church. The Catholic Church was a powerful institution with its own sources of income by which it increased its authority and beyond doubt, it took its power from the interpretation of the holy book. The Bible is an account of word of God, preaching that Jesus forgives the sins and stating that "[n]either is there salvation in any other: for there is none other name under heaven given among men, whereby we must be saved" (Acts $4: 12)$. 
The Bible contains stories of the people from history and some of these stories are about the women. The reason why the holy book has been chosen as the subject matter of this paper is because in some of its stories the women are either represented derogatorily such as being sinful or pictured less important than the opposite sex. In each case, the women are not given the place they merit and the male-female inequality existing in the society gains strength with the Bible. Contrarily, holding some of its verses as their mainstay, Christian egalitarians defend that both sexes are equal for God the Lord. Similarly, $14^{\text {th }}$ century French author Christine de Pizan claims that the women are as intelligent and powerful as the men. To that end, she gives many examples of powerful and intelligent women. Her stories serve as a reply to the ones in the Bible and she tries to refute the misrepresentation of the women in it. Hence, it would be right to consider that she was among the first defenders of equality between the sexes and that she was courageous enough to stand up to the holy book. Taking the holy book as its starting point, this paper seeks to contrast the Bible's representation of the women with Christine de Pizan's in her book the Book of the City of Ladies in the light of Christian egalitarianism.

The position of the women in the society has been a matter of question for centuries and there has been always a misconception that the women are prone to sin more than the opposite sex due to the Original Sin. To conceptualize it, in the Blackwell Dictionary of Sociology, Allan G. Johnson gives us a definition of misogyny:

"Misogyny is a cultural ATTITUDE of hatred for females simply because they are female. It is a central part of sexist prejudice and IDEOLOGY and, as such, is an important basis for the oppression of females in male-dominated societies." (Johnson, 2010:197)

This quotation is quite illuminating to exhibit the unjust treatment towards the women: they are illogically ill-treated simply because they are women; it is a biased insight that they are inferior to the men; it is an ideology started to be constructed in the Bible, and it is the oppression of the patriarchal system. In the light of these key words, we could claim that the Bible has misogynistic verses. In fact, this idea is reinforced by an early Christian author Tertullian (160-220 AD):

"You are the devil's gateway ... you are the first deserter of the divine law; you are she who persuaded him whom the devil was not valiant enough to attack. You destroyed so easily God's image, man. On account of your desert -that is, death- even the Son of God had to die" (Rogers, 1966:15).

The Bible seems to found Christian misogyny through its stories in which the women are represented as either cunning seductresses or silenced, subjugated 
beings. Surely, the best known of these infamous stories is the banishment from the Garden of Eden in which the temptress role is assigned to Eve while Adam in turn sins. Adam does not directly fall into sin due to the serpent like Eve; the sin is introduced through Eve with an emphasis on her sensuality: "[T]he tree was good for food, and that it was pleasant to the eyes" (Gen 3:6).

Similarly, Uriah's wife Bathsheba is appealed by her senses and makes love with King David mesmerized by her beauty when seeing her having a bath. Realizing that she is pregnant, Bathsheba manipulates the king and leads her husband's death. Later, Solomon is born and she marries to David. As the years pass by, David becomes impotent urging the change in throne. Knowing that the eldest son Adonijah's getting the throne will be dangerous for her; Bathsheba cheats the king by saying that Adonijah has usurped the throne while Solomon remains loyal. After getting rid of Adonijah with a cunning plan, Bathsheba becomes the Queen Mother. The story focuses on her adulterous side because she does not remain faithful to her husband; she even tries to deceive him foisting the baby as his although in reality it is King David's plan. On the other hand, the story is suggestive in showing what an intelligent woman Bathsheba is, since she can manipulate the men devising the events according to her own wish. It also both totally disregards man's sensuality as it is actually David who rapes Bathsheba and her victimized situation. Rather, only the end of the story is given much importance and she is depicted as foxy, adulterous, disloyal, devilishly intelligent biblical femme-fatale.

Among many derogatory woman representations, the story of Samson and Delilah sets another example. Samson, a hero of the Israelites, is deceived by Delilah. The lords of the Philistines ask her to discover the secret of Samson's strength in exchange for which they promise "[they] will give [her] every one of [them] eleven pieces of silver" (Judges 16:5). Three times she asks Samson for the secret of his strength and three times he gives her a false answer. On the fourth occasion, he explains that it is his hair and when Samson is asleep on her knees, Delilah calls up her men to shave his hair who also leads to his torturous death. On the surface, the story condemns Delilah, but the closer study of the story raises some questions about the motives of the characters. What is the reason behind Delilah's act? Is she too naïve or too evil? Why do the Philistine men offer silver to her? Is she desperately poor or not? The mentioning of money subtly criticises her for being materialistic and, throughout the story, her emotions are not dealt with. This omission dehumanizes her. However, unless she had good reason to hate all the Israelites, Delilah must have felt some pity. She is an instrument at the hands of the Philistine lords, the story only pinpoints Delilah's malice blaming her for Samson's death, though. She is not the only one to be cursed; the men torturing Samson to death is more villainous. 
In the Bible, beginning from the creation story, the women are generally viewed in a negative light. In Gen 1:27, God is described as creating both the woman and the man at the same time: "So God created man in his own image, in the image of God created he him; male and female created he them." This might be taken as an indication of equality between sexes. In fact, it is through this verse that the egalitarians support their argument. However, we later learn that God formed the man first: "And the LORD God formed man of the dust of the ground, and breathed into his nostrils the breath of life; and man became a living soul" (Gen 2:7). Realising that he needs a helper, God marches all of the animals past while Adam looks for an appropriate companion. Finding none suitable, God creates Eve out of one of Adam's ribs (Gen 2:18-22). The term "helper" has of inferior implication, which is later evidenced by Adam's naming her: “... [S]he shall be called Woman, because she was taken out of Man" (Gen 2:23). It is useful to keep in mind that in ancient times, one was believed to have the authority over a person or a thing by naming it. Thus it is seen that Adam becomes dominant over Eve from the very beginning and this is constructed through Adam's mastership: “... [T]hy desire shall be to thy husband, and he shall rule over thee" (Gen 3:16). These verses prove that man was created first and was given the primacy of leadership. It is also interesting to note that the woman is created in substitution for an animal when Adam cannot choose any of them. This nuance is further supported by Allan G. Johnson's view in The Gender Knot: "[M]isogyny arises out of a system that offers women to men as a form of compensation" (Johnson, 2005:65). Due to her sinful act, Eve becomes Adam's slave, his property. This curse will be passed down to all daughters of Eve; all these women will be inferior at birth and will inherit her subservient role and it is this secondary creation of the female that may suggest her banishment from the society.

Exodus 21:2-4 states that "If thou buy a Hebrew servant, six years he shall serve: and in the seventh he shall go out free for nothing ... If his master have given him a wife, and she have born him sons or daughters; the wife and her children shall be her master's, and he shall go out by himself." This verse gives the possession of the female servant to her master and he has the right to marry her to any of his male servants. It seems that they do not ask the woman's opinion for the marriage. Besides, while the male servant has freedom to leave, the female one does not have any. The female servant is not conferred on; her only duty is to surrender to what has been decided on behalf of her by the males. The woman is doubly colonized both by being a servant to her husband and to her master. To make the matters worse, "[i]f a man sell his daughter to be a maidservant, she shall not go out as the menservants do" (Exodus 21:7). The double standard goes on; even though a male servant is given freedom after six years, a female slave remains a servant -euphemism for a slave- forever. It is clear that the women have no chance of freedom whether they 
are wives or daughters; being descendants of Eve, they have their part in the Original Sin and subordinate they must be to their males.

The third book of Moses -Leviticus- is about the purification of woman after childbirth. It demonstrates that the women are physically inferior because of their natural bodily functions making them unclean in the eyes of God. Moses quotes God's word stating that a woman who has given birth to a boy is ritually unclean for seven days. If the baby is a girl, the mother is unclean for fourteen days. "If a woman have conceived seed, and borne a man child: then she shall be unclean seven days; ... [b] [ut if she bear a maid child, then she shall be unclean two weeks" (Lev $12: 2,5)$. To give birth to a girl is twice worse and the female sex is so detested that their menstrual cycle serves as a pretext to call them inferior. Likewise, in Chapter 15 of Leviticus, it is stated that a woman during her menstrual cycle is unclean for seven days and that any person or thing she touches also becomes unclean. In this respect, a couple cannot have sexual intercourse in this period. If they have, they should be cut off from their people (Leviticus 20:18). Leviticus 27:6 concentrates on the value of the infants:

And if it be from a month old even unto five years old, then thy estimation shall be of the male five shekels of silver, and for the female thy estimation shall be three shekels of silver.

Materializing the babies -a human being- cannot be accepted in the contemporary era and what makes the matters worse is pricing the girl less than a boy. It seems that the babies can be readily seen in materialistic terms and be treated as properties sellable when needed. The birth is one of God's marvels, but neither mothers nor the babies -especially if it is a girl- is given much importance. Despite being the initiator of pregnancy, the father leaves the stage without any responsibility.

Numbers 5:11-31 is about the law concerning jealousy and describes a lengthy magical ritual that the women are forced to perform if their husbands suspect them of having had an affair. It is about the process in which a priest prepares a potion and forces the woman to drink it so that he can understand if she has cheated on her husband. If the woman is guilty, she will suffer a lot and her thigh will get rot because she has already been cursed by the priest and she will be made an "other" in the society. What is interesting is that there is no similar magical test for husbands being suspected of having an affair with another woman and it is clearly a double standard for the women. It is also ironic that the priest behaves against the word of God now that it is known that He has created all humanity in his own image. 
Another double standard and unjust approach is stated in 27:8-10 again in Numbers. Moses describes the rules of inheritance that God has stated:

And thou shalt speak unto the children of Israel, saying, If a man die, and have no son, then ye shall cause his inheritance to pass unto his daughter. And if he have no daughter, then ye shall give his inheritance unto his brethren. And if he have no brethren, then ye shall give his inheritance unto his father's brethren.

When the father dies, his son can inherit the property, but his daughter cannot benefit from the inheritance. The daughter can inherit on condition that the father does not have a son. Similarly, if a man does not have any children, his property is inherited by his brothers and her sisters do not come into anything. If he has no brothers, his property can only be inherited by the closest male kinsfolk. That the women are undervalued is apparent in the First Epistle of Paul the Apostle to the Corinthians, Paul in which he wants the silence of the women. In 1 Corinthians 14:34-35, he clearly expresses his ideas about how a woman should behave:

Let your women keep silence in the churches: for it is not permitted unto them to speak; but they are commanded to be under obedience, as also saith the law. And if they will learn anything, let them ask their husbands at home: for it is a shame for women to speak in the church.

It leaves no suspicion that women should be obedient and silent. Likewise, in his Epistle to the Ephesians 5:22, Paul addresses women and advises them: "Wives, submit to your husbands as to the Lord." He wants submission, because husband is the head of wife. Metaphorically, it may suggest that the males are more intelligent than the females. In the same vein, 1 Timothy 2:11-13 of the Bible states that a woman should learn in quietness and full submission. Paul preaches "Let the woman learn in silence with all subjection. But I suffer not a woman to teach, nor to usurp authority over the man, but to be in silence. For Adam was first formed, then Eve." He again emphasizes that man is the first creation. In 1 Peter 3:1, wives are demanded to be submissive to their husbands. "[Y] we wives, be in subjection to your own husbands; that, if any obey not the word, they also may without the word be won by the conversation of the wives." All these verses, without doubt, demand that women be silent like a toy, like a property which only listens to, but does not respond. As Jewell summarizes in Women in Dark Age and Early Medieval Europe:

Paul's influence on the standing of women in Christian society was immense and uncompromisingly insistent on their inequality in both public and private life. Chapter 11 of 1 Corinthians lays down that the head of every man is Christ, the head of woman is man. (Jewell, 2007:31) 
These verses illustrate that women are treated as second class creatures. It is almost impossible to erase that image of woman, since above all, she was created after Adam and her inferiority is firmly established with the holy book. The Bible is the word of God and thus, woman representations are mightily constructed, the male sex takes its power from the Bible when dominating woman as it is sinful to go against what God says.

Christian egalitarianism, on the other hand, objects to the negative representation of the women by making some verses of the Bible as the basis of its argument. What the egalitarians ask for is the equal treatment for both sexes. According to Collins Cobuild English Dictionary, Egalitarianism "is used to refer to the belief that all people are equal and should have same rights and opportunities." Also known as the biblical equality, Christian egalitarianism advocates that the whole humanity is created equally in the eyes of God. This view covers gender, religion, skin colour and any other differences between individuals. It does not mean that they have the same abilities, characteristics, physical features but suggests that all people are equal before God. Every one of them is responsible to obey the word of God. The egalitarians believe that the teaching of Jesus Christ is the pathfinder for all people without discrimination. In this context, egalitarian view abolishes gender categories and affirms that God has created woman and man to complement each other. In this socially constructed binary opposition of woman and man, neither of the items is privileged.

The egalitarians defend that the sexes are created equally by God as he created mankind in the image of himself. As the Scripture says, "So God created man in his own image, in the image of God created he him; male and female created he them" (Gen 1:27). The key proof to the advocacy of total equality is the verse of the Epistle of Paul the Apostle to the Galatians 3:28 stating " $[t]$ here is neither Jew nor Greek, there is neither bond nor free, there is neither male nor female: for ye are all one in Christ Jesus." It evidences that everybody is one and any distinctions are invalid in Christ. Regardless of their social, cultural, biological, or racist background, all human beings should be treated indiscriminately. In this context, egalitarians believe that the submission of the women is not compatible with the nature of biblical equality. Now that God has created human beings in his own image, they are unique before him and they are individually responsible for their acts and no one is another's property.

It is indubitable that the Church establishes its power by making use of or manipulating some verses of the holy book throughout the Middle Ages. Supporting their (mis)representation of the women with a number of verses, the clergy made people - even the women- believe that the women are the second sex and that they 
are not endowed with certain skills. However, there was one woman who could see through this: Christine de Pizan. Living at the close of the Middle Ages, Pizan realized that the women did not lack anything to be called as the lower sex and with her work, she reacted against the established order of the Church and the society.

Born in 1364, Christine de Pizan became the early spokesperson for the Christian egalitarians with her medieval text The Book of the City of Ladies originally Livre de la Cité des Dames. Her work is commonly recognized as the first feminist text since Pizan directly opposed misogyny in it. To give a historical data, "[i]t is not until the $14^{\text {th }}$ century that there appears a woman writer determined and able to plead for her sex and to take a stand against the prevalent denigration of women" (Power, 1995:4). The egalitarian ideas against the discrimination of sexes can be observed in the book. Thus, Pizan's work can be taken as a moral defence of the women establishing its argument on the idea of biblical equality and confronting the biblical representation of the women. Maureen Gillespie Dawson notes the aim of the work as follows:

[It] is to contest the contemporary, pervasive belief that women are unintelligent, unfaithful, insatiable, and immoral. The book systematically challenges what men have written about women; it builds an alternative, authoritative female identity grounded in the intellectual, artistic, and moral contributions of women. (Dawson, 2005:17)

To this end, Pizan provides us with many characters. While relating their stories, she seems to answer the unwarranted attacks of the Bible. The Book of the City of Ladies begins by depicting the process by which the character Christine accepts the judgment of her oppressor and consequently despises herself. The opening scene of the work describes Christine looking at a book by Matheolus- $13^{\text {th }}$ century French poet. At the beginning of the work, Christine is ready to succumb to the misogynist views of the male authorities she has read, especially Matheolus when she sees "It is all manner of philosophers, poets and orators too numerous to mention, who all seem to speak with one voice and are unanimous in their view that female nature is wholly given up to vice" (Pizan, 1999:6). She relates that she "had to accept their unfavourable opinion of women since it was unlikely that so many learned men...could possibly have lied on so many different occasions" (6). Luckily, just as she is about to be overwhelmed by self-contempt and despair because she is female, the three daughters of God-Reason, Rectitude, and Justice-appear and engage her in the task of building a city of women, a project whose "wish is to prevent others from falling into the same error as [Christine] and to ensure that, in future, all worthy ladies and valiant women are protected from those who have attacked them" (11). The three ladies list numerous examples to refute the unjust stereotyping in the Scripture. Pizan presents us many women characters from the 
holy book, history, literature, and mythology. To highlight the capabilities and virtues of numerous women, the work counters misogynist voices. Pizan retells the past achievements of the women; she emphasizes the spiritual, intellectual, and physical power of them by which she tries to persuade that they are as praiseworthy as the males. Hence, her allegorical city serves both as a shelter for the accusations of the opposite sex and as a gated community for the women. As Christine declares, the city is a safe place in which the women can find peace without the sexual aggression and cruel attacks of the men. The city becomes the embodiment of the strength of and the camaraderie between the women.

Just as it grows bigger brick by brick, Pizan's argument gains strength story by story. She tells stories from the past and present to exhibit the on-going intellectual development of the women. Christine de Pizan, speaking through Reason, first refutes the Story of Creation that God created man earlier than woman and thus, she is inferior and servant to him. She says after creating Adam from the clay of the fields of Damascus, God put Adam to sleep in heaven and "created the body of woman from one of his ribs. This was a sign that she was meant to be his companion standing at his side, whom he would love as if they were one flesh" (22). Pizan shows that actually woman and man are of one unity; created for each other without any privileges. Reason further explains that God endowed both the male and female with his soul, which He made indiscriminatingly virtuous and noble in both sexes. Lady Reason summarizes her ideas when she puts that "human superiority is or inferiority is not determined by sexual difference but by the degree to which one has perfected one's nature and morals" (23). It is safe to conclude that Pizan's view overlaps with the ideas of Christian egalitarianism while putting away the ones in the Bible. Pizan praises the ones who have cultivated his/her intellect, spirituality without taking into consideration the sex differences.

She advances her opinion by exalting Eve as much as Mary -qualifying both as holy saviours. She asks for equality between a seductively-(mis)represented evil woman and a passive virgin one. She replies to those seeing woman as inferior as such:

It is thanks to a woman, the lady Eve, that man was expelled from paradise, my answer to them would be that man has gained far more through Mary than he ever lost through Eve. Humankind has now become with God, which never would have happened if Eve hadn’t sinned" (23).

She develops a brave idea almost rebelling against the tenet of the holy book. What makes her the defender of egalitarianism is that she considers equal both the sinful Eve and the innocent Mary. Pizan's later comments oppose what Apostle Paul 
demands in his Epistle to Corinthians, Ephesians and Timothy. Silence is the fundamental point he is asking for, to which Pizan does not yield. She supports his view with a historical fact and defends the women: "If women's speech had been as unreliable and worthless as some maintain, Our Lord Jesus Christ would never have allowed news of such a glorious miracle as his resurrection to be announced first by a woman, as he told the blessed Magdelene to do" (27). While Paul wants total submission from the women, the task to spread the news gives them an authority. She reinforces her thesis with the request of Jesus for declaration of resurrection by a woman. Contrary to what Apostle Paul and the Bible express, Pizan's argument is against the speechlessness of woman. "You can now surely see that God gave women the power of speech so that they might serve Him. They shouldn't therefore be criticized for something which has done so much good and so little harm" (28). She concludes that gift is given by God and the males cannot interfere with it. It is the women's choice to speak or not and the men should not limit their freedom of speech. Pizan implies that the two sexes are equal and they can speak when/wherever they wish.

To illustrate her point that the women can be as intelligent as the men, Pizan lists many examples from history. Contrary to the ideas put in Exodus and Leviticus, she hints that the women are not the property of the men and that they have their own value, intellect, and mind. She explains that they are capable of making important inventions. Her first example is Minerva, a maiden from Pallas, who "invent[ed] various Greek letters called characters" (66). She also adds that it is Minerva who invented tools for weaving, to make oil from pressing olives, to build carts and chariots, to forge armour for knights, to organize them into armies. She elaborates the topic with Isis, who discovered the art of making gardens and growing plants. Her evidence suggests that the women can embark on an enterprise rather than being merely submissive and silent. They can give voice to their ideas and shape the society with their inventions now that they have the ability to work for the benefit of community.

Another portrait is the Queen Ceres of Sicilians, who invented both science and the techniques of agriculture. Besides, she taught people to build proper towns and cities and to live in communities. Pizan expands her entrepreneur women with Isis, who discovered the art of making gardens and growing plants; maiden Arachne, who invented the art of dyeing wool and of weaving tapestry. Her examples indicate that the women have the skill to invent, to produce, and to become leaders. Those women stand quite contrary to what the Scripture demands: submission and silence. Pizan articulates that the women are not weak, brainless creatures deserving to be degraded, who cannot survive without protection of a man, but powerful, intellectual ones who can manage to live alone and what is more, who can undertake leadership. 
Pizan enhances her examples with Sappho, who was an extremely fine poet and philosopher. She tries to mark that as well as martial skills and being devoted wives, the women can similarly be successful in fine arts. From the city of Mytilene, Sappho was a very beautiful maiden with her superb intellect. She was an expert in many different arts and sciences and she was also a prolific author. She invented new forms of song and poetry from lays to complaints and elegies. Horace recalls that her book was found under the pillow of Plato and Pizan exalts her with Boccaccios's comments: "Sappho, spurred on by her fine mind and burning desire, devoted herself to her studies and rose above the common ... she immersed herself in arts and sciences ... she learnt the art of musical chords as well as the rules of harmonics" (60-61). By quoting from Boccaccio, Pizan strengthens her argument. Thereby she implies that it is not her but a man praises a woman. Boccaccio accepts that a woman can be better than the common people through her diligence and gift. His view corresponds to the idea that men are not the only ones who have the monopoly of intellect and various abilities. When given education, each individual is capable of improving her/himself. It is what Jewell states in Women in Late Medieval and Reformation Europe:

"In Chapter 27 of Book I of the City of Ladies [Pizan] had Reason pointed out that if it were customary to send daughters to school like sons, and if they were then taught the natural sciences, they would learn and understand as thoroughly as men" (Jewell, 2007:152).

In the same vein, Catherine reproaches that the men thinks the women cannot do anything for the welfare of humanity but they can only bear children and spin wool. Lady Reason consoles her by saying that God has given not only the capacity to learn and grasp all kinds of knowledge but also to invent new ones by themselves. This idea can be taken as the early foundation of the egalitarian view and it is also against the Apostle Paul's claim that the women can only be taught by the men and that they cannot progress by themselves. Lady Reason mentions Carmentis, whose "invention of the Latin alphabet pleased God so much that He wished it to replace the Hebrew and Greek alphabets" (70). It is a striking example to demonstrate that it is thanks to a woman that the humanity has been brought out of their ignorant state and become civilized. It is through the alphabet that the humans have learnt to transmit their messages and emotions all over the world. She closes up the matter cynically with the below quotation:

In short, it is impossible to count up all the advantages that the invention of the alphabet has brought: it is writing which allows us to describe and to know God's will, to understand celestial matters, the sea, the earth, all individuals and all objects. I ask you, then, was there ever a man who did more good than this? (71). 
Another interesting story is about Saint Christine the virgin, the daughter of Urban, governor of the city of Tyre. Christine's patron and namesake, she is among the most striking and courageous women of the book. From the age of twelve, she "wants to offer herself untainted to the Lord" (218) and Saint Christine has become unforgettable when she refused to worship her father's gold and silver idols, which she smashed and gave to the poor. As a result of this, she was exposed to torture. She was put to chains and imprisoned; she was stripped and whipped with her arms and legs tied down; her tongue and breasts were cut. Every time God's hand touched her and she was saved by the holy saviour, which her father calls to be witchcraft. In the end she was summoned by heavens and she became a martyr for the sake of her unshakeable love of and belief in God. Thereby, she paved the way for thousands of conversions. Saint Christine is the perfect example of boldness, loyalty to God and patience. Even though she undergoes many tortures, she does not lose her faith in God. She stands upright alone against her tyrannical, brutal father, which again shows that the women does not necessarily be subjective and can find the truth by themselves without the guidance of a man. Her story also shows the cruelty of a father whose daughter's mere crime is to follow God rather than the pagan gods her father ordered her to worship.

Pizan honours all kinds of women and gave them a place safe from the attacks of the men. The Book of the City of Ladies is a testimony to the grandeur and various accomplishments of the women, elevating them to the same level with the men. Similar to the construction of the Bible, Pizan's work contains many stories. As exemplified earlier, the difference stems from the opposite representations of the women. While in the Bible, Bathsheba is treated as destroyer, Pizan presents Queen Artemisia and Fredegunde to counteract her, for instance. Artemisia, the noble Queen of Caria is represented with "all the right qualities needed to rule a country, being honest, sober in manner and politically astute" (50), keeping the realm unified. She achieves several victories and governs the state wisely. Being a fearless warrior and sharp military strategist, she conquered the Rhodes Island and defeated Xerxes, King of Persia to help the Greeks. Besides being a good leader, she was also a devoted wife. After her husband's death "she mixed his ashes with some liquid and drank them down, little by little, over a period of time until she swallowed every last drop" (113). Her manners portray her as a very loyal wife and queen. She establishes herself a brave leader and proves that a woman can survive and accomplish many deeds without the support of a man. Likewise, Pizan gives the example of Queen Berenice of Cappadocia to refute the (mis)conception that the women are fragile, passive, and timid. She relates that when the lady is left widow, one of her husband's brothers tried to disinherit her and kills two of Berenice's sons. Upon this occasion, Berenice leaves all her womanly timidity and attacks her brother-in-law with a huge army at the end of which she gains victory. The example shows that the 
women can be triumphant without the help of a man and even against a man by themselves.

By the same token, Queen Fredegunde takes the place of a powerful king and heartens her barons during the battle. She becomes the leader, directing the troops. That she was also a great military strategist understood when she appealed to the psychology of the soldiers. She brought her baby son into the battlefield so that she could hearten them to win the battle at all costs to secure the future of the kingdom. She also had the horses camouflaged and then she instructed the soldiers to tie bells to their mounts, which the enemy mistake for grazing animals, allowing Fredegunde's forces to penetrate the enemy camp. Her military genius is apparent and needless to say, she could overcome the difficulties by herself. Artemisia and Fredegunde are not destructors, but they are the savers of their kingdom. They have courage to take action and moral insight to protect their subordinates. These active woman profiles do not comply with Apostle Paul's submissive women. It would be meaningful to ask which one of these women is more beneficial for the welfare of the society. The stories of these women are also proofs for the egalitarians. Pizan shows that the women can have good conduct of throne; they can fight as mighty warriors do. She shows that the females can be as smart and strong as the males. As well as suggesting equality, these stories oppose Bathsheba's as Artemisia and Fredegunde are the flourishers of a community.

Pizan details her praise of the women with references to Queen Artemisia, Queen Hypsicratea, the Empress Triaria and many more women for the great love that they have for their husbands. She talks about several ladies, who saved their husbands from execution. She gives examples to contradict to those who claim that few women are chaste. She lists proofs to refute the view that women are lacking in constancy and Rectitude mentions various examples of emperors who were unreliable and inconsistent such as Nero or the Emperor Galba. She also refutes the opinion of those who claim that women are by nature mean recalling the generous and wealthy woman Busa.

Through these figures, Christine strives to prove that women are not only meant to be treacherous beings. She argues that the desirable, positive qualities are not bestowed upon the men, while the women are degraded. As long as each sex is intelligent and cultivated enough, they should be treated equally. "Christine argues that the two sexes are equal, at least in terms of their propensity for virtue"(BrownGrant, 1999:174). Pizan tries to shatter the traditional belief that domestic sphere is where the women belong to. In turn, she provides us with countless woman profiles as warriors, poets, authors, inventors, political and military leaders. It is important to note that Christine is not trying to elevate only the women at the expense of the men 
but struggling to create a balance between the sexes. She does not have a sexist attitude towards the men. She just asks for equality and she attempts to eradicate the differences between two sexes to illustrate that it is through the collaboration of them that the world has been developing. In her battle of the books, the representation of the characters in the Bible is paired and clashed with the ones in the City of Ladies. Pizan refutes the creation story and the stories of Batsheba and Delilah with the stories of Queen Fredegunde and Queen Artemisia. Exodus', Leviticus', and Numbers' views of the women as inferior, having no liberty to act since being the property of the men is counteracted with the experiences of Saint Christine, Queen Berenice, Sappho and Minerva, Isis, Arachne, Ceres the Inventors. With her remarks, she becomes one of the forerunners of Christian egalitarianism and acts brave enough to go against some narratives of the Bible. Although it is clear that it would be difficult to shatter the stereotypes established in the holy book, Pizan's struggle is of great importance for her followers. It is not surprising that she is listed among the long lasting literary figures since what she tried to do in the dark passage of the Middle Ages is pursued after many centuries by the feminist authors and egalitarians. 


\section{BIBLIOGRAPHY}

Brown-Grant, Rosalind. Christine de Pizan and the Moral Defence of Women: Reading Beyond Gender. Cambridge: Cambridge University Press, 1999.

Dawson, Maureen Gillespie. "Weeping, Speaking, and Sewing: Teaching Christine dePizan's The City of Ladies." Studies in Medieval and Renaissance Teaching, 12.1 (Fall 2005): 5-26. Edition, 2006.

"Egalitarianism.”Collins Cobuild Advanced Learner's English Dictionary. New

Jewell, Helen M. Women in Dark Age and Early Medieval Europe c.500-1200. Basingstoke: Palgrave MacMillan, 2007.

----. Women in Late Medieval and Reformation Europe 1200-1550. New York: Palgrave MacMillan, 2007.

Johnson, Allan G. The Blackwell Dictionary of Sociology: A User's Guide to Sociological Language. Massachusetts: Blackwell Publishers Inc., 2000.

----. The Gender Knot: Unraveling Our Patriarchal Legacy. Philadelphia: Temple University Press, 2005.

Pizan, Christine de.The Book of the City of Ladies. London: Penguin Books, 1999.

Power, Eileen. Medieval Women. Cambridge: Cambridge University Press, 1995.

Rogers, Catherine M. The Troublesome Helpmate: A History of Misogyny in Literature. Seattle: University of Washington Press, 1966.

The Holy Bible, Containing the Old and New Testaments King James Version. 20 December 2010. www.gasl.org/refbib/Bible_King_James_Version.pdf 